Кияшко О.М., к.е.н.

Київський національний торговельно-економічний університет м. Київ, Україна

\title{
ВЕКТОРИ СТРАТЕГІЧНОГО РОЗВИТКУ ОСВІТИ ТА НАУКИ В УКРАЇНI
}

Стратегічний розвиток України зазвичай спрямовується векторально на галузі, які потребують особливої уваги та розвитку. Початок 2015 року ознаменувався прийняттям Указу президента «Стратегія сталого розвитку України 2020» [1]. Зазначеним нормативно-правовим актом увага розподілена наступним чином: вектор розвитку, вектор безпеки, вектор відповідальності, вектор гордості. Розвиток освіти віднесли до вектору відповідальності, а науку до вектору гордості. Розвиток зазначених акцентів підтверджено у векторі відповідальності за освіту - Реформою Освіти, а векторі гордості Реформою державної політики усфері науки та досліджень [1]. Деталізацію реформи освіти та науки зазначено на web сторінці урядового порталу КМУ [2].

В підтвердження стратегічних спрямувань щодо освіти та науки нормативно-правовими актами акцентовано увагу на місії, функціях, стратегії МОН [3] та завданнях МОН [4].

Реформа вищої освіти в Україні передбачає втілення наступних етапів: 1) створення системи забезпечення та постійного поліпшення якості вищої освіти, яка відповідає рекомендаціям і стандартам Європейського простору вищої освіти; 2) забезпечення економічної доброчесності; 3) підвищення рівня підготовки фахівців та забезпечення дотримання норм доброчесності та рівності вступу до закладів вищої освіти; 4) ключові результати, де у підтвердження стратегічного розвитку вказано: «Україною отримано окреме вікно для фінансування конкурсів Програми «Еразмус+» у 2019-2020 роках: виділено додаткове фінансування за напрямом Кey Action (KA)1 «Міжнародна кредитна мобільність» у розмірі 2,5 млн євро, напрямом Key Action (KA)2 «Розвиток потенціалу вищої освіти» - у розмірі 2 млн євро, а також 1,5 млн євро - за напрямом Жан Моне» [2]. 
- Реформаторські кроки для розвитку науки зазначено у п. 4 «Нова система управління та фінансування науки», які передбачають: 1) утворення Національної ради з питань розвитку науки і технологій; 2) утворення Національного фонду досліджень та формування органів його управління Основною функцією Національного фонду досліджень; 3) забезпечення процесу утворення державних ключових лабораторій та отримання статусу дослідницького університету національними закладами вищої освітиа також 4) ключові результати (Утворено Національний фонд досліджень; Затверджено план заходів щодо реформування вітчизняної наукової сфери; створено 8 міжуніверситетських центрів колективного користування науковим обладнанням у закладах вищої освіти;

- Збільшено в 1,63 рази загальний обсяг фінансової підтримки наукових проектів та стипендіальних програм для молодих вчених (до 94 869,5 тис. грн); розширено доступ до електронних наукових баз даних Scopus та Web of Science для науковців, студентів, аспірантів за кошти державного бюджету: у 2017 році до Scopus отримали підключення 67 закладів; до Web of Science - 64 заклади, у 2018 році до Scopus - 135, до Web of Science - 105. Українські науковці стали вп'ятеро частіше користуватися Scopus та Web of Science.

Зазначені кроки та заходи заохочують викладачів, науковців, студентів до плідної співпраці та розвитку як вищої школи, так i науки, а також підтверджують стратегічне спрямування нашої країни до європейської наукової та освітньої спільноти.

\section{Список бібліографічних посилань}

1. Про стратегію сталого розвитку «Україна - 2020»: Указ Президента України від 12 січня 2015 р. - Режим доступу : https://zakon.rada. gov.ua/laws/show/5/2015?find

2. Реформа освіти та науки. Урядовий портал. - Режим доступу : https://www.kmu.gov.ua/ua/diyalnist/reformi/reforma-osviti

3. Місія, функції та стратегія МОН. - Режим доступу : https://mon.gov.ua/ua/ministerstvo/pro-ministerstvo/misiya-ta-funkciyi

4. Положення про міністерство освіти і науки: постанова КМУ від 16 жовтня 2014 р. зі змінами і доповненнями. - Режим доступу: https://zakon.rada.gov.ua/laws/show/630-2014-\%D0\%BF?find 